\title{
A hybrid constructed wetland combined with microbial fuel cell for boron (B) removal and bioelectric production
}

\author{
Onur Can TÜRKER ${ }^{1 *}$, Anıl YAKAR ${ }^{2}$
}

\begin{abstract}
This study deals with performance assessment of a hybrid constructed wetlandmicrobial fuel cell (HCW-MFC) for boron (B) treatment and bioelectric production. Our innovative $\mathrm{HCW}-\mathrm{MFC}$ is first literature report testing for $\mathrm{B}$ removal and bioelectric production at the same time in terms of an eco-technological perspective. The results indicated that 63.4 percent $\mathrm{B}$ removal was achieved for wastewater containing an average $12.3 \mathrm{mg} \mathrm{L}^{-1}$ inflow of B concentrations. Furthermore, HCW-MFC was able to remove $47.5 \%$ and $19.1 \%$ nitrate and nitrite from wastewater, respectively. The maximum power and current density was recorded as $78 \mathrm{mWatt} / \mathrm{m}^{2}$ and $105 \mathrm{~mA} / \mathrm{m}^{2}$ for the last unit of the hybrid system, suggesting that the power and the current density were decreased with the increasing $\mathrm{B}$ concentration. We found that some soil enzymes such as dehydrogenase and urease in wetland matrix strongly correlated with bioelectric production, thus these enzymes might play important roles in bioelectric production with HCW-MFC.
\end{abstract}

Keywords: Hybrid constructed wetlands, microbial fuel cell, boron (B) removal, bioelectric production, soil enzymes 


\section{Introduction}

Both natural as well as anthropogenic activities such as using agrochemicals, production of cleaning products, and mining operations lead to contamination of receiving water body and aquatic environments with excessive boron (B) (Hasenmueller and Criss 2013, Turker et al. 2013, Davis et al. 2002). In recent years, the contamination of aquatic ecosystems with elevated concentrations of $\mathrm{B}$ have aroused more and more worldwide environmental and health attentions given to the potential toxicity effects of $\mathrm{B}$ on crops, plants, animals, and humans (Schoderboeck et al. 2011). Specifically, Drinking-Water Quality Committee recommended a safe limit of B lower than $2.4 \mathrm{mg} \mathrm{L}^{-1}$ (Wolska and Bryjak 2013). Hence, it is important to control B in water environment considering the strict environmental production regulation and public health concerns.

Several conventional treatment methods including membrane process, ion exchange, and adsorption techniques have been applied for the removal of B from various types of wastewater (Wolska and Bryjak 2013). However, methods based on conventional strategies are expensive and require costly equipment apparatus or chemicals for B removal (Türker et al. 2014). In comparison to conventional techniques, constructed wetlands (CWs) have experienced significant advancement in recent years to remove pollutants from contaminated water due to their simple operation guide, eco-friendly properties, and cost effectiveness (Vymazal 2013).

It is noted from the literature that some effective researches showed that CWs' potential of removing and controlling B in the wastewater (Türker et al. 2014). Most studies from literature to date have focused on subsurface flow CWs (Allende et al. 2014, Türker et al. 2016, Kröpfelová et al. 2009), with much fewer researches conducted in surface flow CWs associated with different wetland plants, media, climatic conditions, and wastewater characteristic (Ye et al. 2003, Allende et al. 2012). According to these literature data, CW 
treatment technologies as both subsurface and surface flow systems are seen as an attractive solution to remove B from various types of wastewater, however, to our knowledge, a hybrid constructed wetland (HCW) has never been used for the removal, and control of B from wastewater sources; so one of the aims of this study was to fill these gaps in literature.

The CW systems combined with microbial fuel cell (CW-MFC) technologies is an innovative technology to achieve the object of both wastewater treatment and bioelectric production at the same time (Oon et al. 2015, Corbella et al. 2015, Doherty et al. 2015a). In this systems, bioelectric is produced with biodegradable substances through bacteria oxidized organic or inorganic matter present in wetland matrix (Oon et al. 2015). Particularly, CWMFC system is predominantly used to treat sewage, also examples of treatment of different types of wastewater such as azo-dye wastewater (Fang et al. 2015, Yadav et al. 2012) and swine slurry wastewater (Doherty et al. 2015b) have been documented as well. However, there is no information about the use of a constructed wetland system combined with microbial fuel cell (CW-MFC) to treat wastewater which contains both nitrogen substances and excessive B. Accordingly, numerous types of wastewater sources such as domestic, municipal, and industrial contain both nitrogen substances such as nitrate or nitrite and enriched B due to the presence of sodium perborate in detergents or cleaning products, glass production, and mining effluents (Hasenmueller and Criss 2013, Turker et al. 2013, Schoderboeck et al. 2011, Türker et al. 2014). So, these compositions of wastewater sources make a CW-MFC suitable and potentially applicable method for treating wastewater by removing both nitrogen substances and $\mathrm{B}$, as well as generating electricity in an eco-friendly and economical way. It is important to the note that a HCW-MFC was developed for the first by testing $\mathrm{B}$ removal and bioelectric production at the same time in terms of an ecotechnological perspective. Furthermore, we suggested that the results from the present study 
could be meaningful in assessing the potential of HCW-MFC as an effective solution to generate electricity while remediating wastewater sources contaminated with B.

As mentioned above, the objectives of the present study were to reveal information (i) to assess the performance of a HCW system to remediate wastewater containing $\mathrm{B}$ and nitrogen substrates such as nitrate and nitrite; (ii) to investigate the feasibility of MFC integrated with $\mathrm{HCW}$ in order to produce bioelectric during the B purification process; (iii) to determine the relationship of some important soil enzyme activities such as dehydrogenase, urease, as well as phosphatase with bioelectric production in HCW-MFC.

\section{Materials and Methods}

\subsection{Design of wetland units and culture period}

The experiment was carried out in a growth chamber under the following controlled conditions: $24 \pm 2{ }^{\circ} \mathrm{C}$, photosynthetic photon flux density $85 \mu \mathrm{mol} \mathrm{m} \mathrm{m}^{-2} \mathrm{~s}^{-1}$, and a photoperiod of continuous light. The prototype of HCW-MFC was fabricated and designed using polyester chambers with $45 \mathrm{~cm}$ length, $45 \mathrm{~cm}$ width, and $40 \mathrm{~cm}$ depth. Briefly, the hybrid systems consisted of two constructed wetland units. The first unit was operated according to surface flow design guide based on a flow regime which kept always the water level about $5 \mathrm{~cm}$ above the filtration media. The second unit was a typical horizontal flow subsurface unit which employed gravity feed using $1.5^{\circ}$. In this study, organic based peat and sand mixture were selected as the filtration media for HCW-MFC. It was thought that type of filtration media will not only improve retained $\mathrm{B}$ in the $\mathrm{HCW}-\mathrm{MFC}$ due to a ligand exchange mechanism related to diol or cis-diol complexes but it can also present an ideal environment for microorganisms associated with bioelectric production (Türker et al. 2016, Doherty et al. 2015b). Approximately $5 \mathrm{~cm}$ of gravel was also placed on the filtration media and outflow section. Cattail (Typha latifolia), a popular wetland macrophyte used as phytoremediation of 
103 B in CWs, was used in this study (Turker et al. 2013, Ye et al. 2003). Rhizomes of T.latifolia

104 were collected from a wetland habitat located in Eskişehir, Turkey (39 $\left.17^{\prime} \mathrm{N}, 30^{\circ} 30^{\prime} \mathrm{E}\right)$, and

105 the rhizomes were immediately transplanted in wetland units at a plant density of about 12

106 rhizomes $/ \mathrm{m}^{2}$. A horizontal rectangular $(4 \mathrm{~cm} \mathrm{x} 6 \mathrm{~cm}$ and $1 \mathrm{~cm}$ thickness $)$ magnesium cathode

107 was located above filtration media and in the gravel layer (Yadav et al. 2012). Two graphite

108 anodes $\left(100 \mathrm{~cm}^{2}\right.$ surface area) were also placed into organic based peat and sand mixture in

109 the HCW-MFC (Oon et al. 2015). A glass wool layer (0.01 thickness) was placed in the

110 HCW-MFC in order to separate the cathode and anode compartments (Yadav et al. 2012).

111 Finally, the cathode and anode were connected with insulated copper wires across a $1000 \Omega$,

112 and the distance between the cathode to the anode 1 and the anode 2 were 10 and $20 \mathrm{~cm}$,

113 respectively (Corbella et al. 2015). The detailed schematic demonstration of the HCW-MFC

114 is also given Fig 1.

115 Prior to the experiment start up, the HCW-MFC was fed with mixture of Hoagland

116 medium and sludge for 45 days in order to support the cattail growth and establish

117 microorganisms (Oon et al. 2015). Furthermore, the sludge was collected from a treatment

118 plant for industrial wastewater, and the sludge was mixed in the Hoagland medium and then

119 poured into the HCW-MFC. In this respect, we believed that this composition of mixing

120 sludge contains both essential minerals for plants and active microorganisms associated with

121 bioelectric production.

\subsection{Boron dosage and Operation of wetland units}

After cultivation in a period of 45 days, the HCW-MFC unit was fully established for

125 B treatment facility and bioelectric production under the controlled conditions. In the present

126 experiment, the study was carried out with simulated wastewater obtained with Hoagland

127 medium contaminated with various $B$ concentrations of $\mathrm{H}_{3} \mathrm{BO}_{3}$ dissolution (Merck, 
128 purity>99) arranged in a geometric series: $2,4,8,16$, and $32 \mathrm{mg} \mathrm{L}^{-1}$. The simulated

129 wastewater resembling pollutant level in the surface water and some sewage in Western

130 Anatolia, Turkey was prepared (Hasenmueller and Criss 2013, Türker et al. 2016). These

131 types of water sources were selected as references because of their high levels of B, as well as

132 relatively higher concentrations of nitrate and nitrite (data not shown). The simulated

133 wastewater was stored in a $100 \mathrm{~L}$ polyethylene inflow tank which was continuously stirred.

134 The wastewater was freshly prepared for each experimental group before the first dosing, and

135 this wastewater sample was kept until the next dosing day on the same week (Allende et al.

136 2014). The wetland units were operated under the same hydraulic loading rate of $20 \mathrm{~mL} / \mathrm{h}$ and

137 dosed every 8 hours over the periods of $24 \mathrm{~h}$, so the hydraulic retention times of the each unit

138 were to set to 7 days. On the other hand, the outflow water from unit 1 was stored in the

139 outflow tank 1 , and then this water was immediately dosed to unit 2 . The mean outflow rate

140 was figured out according to Allende et al. (2014), and each dosing event took $30 \mathrm{~min}$.

141 Moreover, the outflow water from unit 2 was collected in outflow tank 2. The wetland

142 operated under a continuous process mode, and the wastewater followed the flow direction in

143 the cathodic compartments both unit 1 and unit 2.

\subsection{Bioelectric production monitoring and measurement}

146 The bioelectric production performance of the unit 1 and unit 2 were determined with

147 daily measurements of the voltage drop (V) across the external resistor using a digital

148 handheld multimeter (Fluke CNX 3000 wireless) described before (Zhao et al. 2013).

149 According to this procedure, the cathode and anodes were connected with wires and 150 resistance, and then the potential between edges of the resistance were continuously

151 monitored. Moreover, power density was calculated by dividing the power and current by

152 surface area $\left(\mathrm{m}^{2}\right)$ of anode (Oon et al. 2015). After the $70^{\text {th }}$ day of operation, polarization 
153 curves were determined by varying the external resistance from $1 \Omega$ to $680.000 \Omega$ finally to

154 infinity at open circuit and measuring the steady state voltage across the resistor within 15 $155 \min$ (Doherty et al. 2015a, Doherty et al. 2015b, Logan et al. 2007).

\subsection{Chemical analysis of water, plants, and media from $\mathrm{HCW}-\mathrm{MFC}$}

\subsubsection{Wastewater sampling and analysis} time (7 days) of wetland units, and psychochemical parameter such as $\mathrm{pH}$, electrical the laboratory according to the standard methods (APHA 1998). Nitrate and nitrite in water samples were measured with a colorimetric method using a colorimeter (HACH DR/890) immediately after sampling.

\subsubsection{Plant monitoring, biomass production, chemical analysis, and pigment concentrations}

The height of cattail was monitored every four days, and any instances of plant disease were recorded. Cattail height was calculated as the average height of leaves in the HCWMFC. On the other hand, all the cattail biomass both aboveground and belowground was

172 composition of the plants at the end of the experiment. Dry biomasses of cattail were 173 calculated by drying the harvested biomass in an oven at $65^{\circ} \mathrm{C}$ for $48 \mathrm{~h}$. After calculating, the

174 plant parts were separated into leaves, stems and roots/rhizomes, and all the material were 175 powdered and digested by $\mathrm{HClO}_{4}: \mathrm{HNO}_{3}$ acid at $1: 3$ proportion in a microwave digestion unit

176 in order to determine B concentrations (Turker et al. 2013). Moreover, N content was 177 determined by the Kjeldahl method. 
1791 and unit 2 were also measured during the experiment period. For the analysis, fresh tissues

180 from mature leaves of T.latifolia were collected every four days from the units, and

181 photosynthetic pigments were determined according to (Wellburn 1994).

182

183

184

185

186

187

\subsubsection{Filtration media analysis and soil enzyme activities}

The media samples from the units were collected homogenously at the end of the experiments. The samples were collected using a 4-cm diameter PVC corer. The concentration of $\mathrm{B}$ was determined by atomic absorption spectrometry method. The extractable B (plant available B) in sediment was measured by carminic acid method, $\mathrm{N}$ by Kjeldahl method and soil structure by Bouyoucos method (Turker et al. 2013).

Moreover, rhizosphere samples from the units were also collected every 4 days using hand-shaking method in order to determine the correlation existed between enzyme activities and bioelectric production in HCW-MFC (Zhang et al. 2010). In this respect, we measured the activities of 3 important enzymes in the rhizosphere of HCW-MFC. Those enzymes have crucial role associated with the cycling of carbon (dehydrogenase), nitrogen (urease), and phosphorus (phosphatase) (Zhang et al. 2010). The collected media samples were sieved and then stored in refrigerator at $4{ }^{\circ} \mathrm{C}$ prior to analysis of enzyme activity within one week. The dehydrogenase, urease, and phosphatase enzyme activities in rhizosphere of the units were determined (Kong et al. 2009).

\subsection{Calculation and statistical analysis}

Boron removal performance $(\%)$ from wastewater though unit 1and unit 2 was calculated as follows:

$$
\text { B removal performance }(\%)=\left[\left(C_{i} V_{i}-C_{e} V_{e}\right) / C_{i} V_{i}\right] \times 100
$$


where $C_{i}$ and $C_{e}$ are the average B concentrations of inflow and outflow in $\mathrm{mg} \mathrm{L}^{-1}$;

$204 V_{i}$ and $V_{e}$ are the volumes of the outflow and the inflow collected and dosed into units.

The mass removal rate (MRT) of the HCW-MFC calculated using equation evaluated

by (Türker et al. 2016):

$$
\text { Mass removal rate }\left(\mathrm{mg} \mathrm{m}^{-2} \mathrm{~d}^{-1}\right)=\left[\left(C_{i} \mathrm{x} V_{i}-C_{e} \mathrm{x} V_{e}\right) / \text { unit surface area/ HRT }\right]
$$

Total area of HCW-MFC was $0.405 \mathrm{~m}^{2}$ and Hydraulic retention time (HRT) was 7 days describe in above.

Current ( $I$ ) was determined by according to Ohm's law using formula: $I=V / R$ where $V$ corresponds to cell voltage, and $\mathrm{R}(\Omega)$ is the external resistance.

$$
\text { Power (W) is determined by using formula: } P=I x R
$$

where I corresponds to current (A) and V (V) is cell voltage. Moreover, power density was calculated by dividing the power and current with surface are $\left(\mathrm{m}^{2}\right)$ of anode (Oon et al. 2015).

Statistical between the concentrations of $\mathrm{B}$ and $\mathrm{pH}, \mathrm{EC}$, and temperature value in inflow and outflow water samples both unit 1 and unit 2 were determined a one-way ANOVA test. Correlations between soil enzyme activities and bioelectric production in the units were analyzed by Pearson's correlation coefficient. Prior to performing ANOVA, the data from the present experiment were checked for normality and homogeneity of variance (using the Shapiro-Wilks test) with significance set at 0.05 . Statistical confidence was set at $p<0.01$ and $p<0.05$. All statistics were implemented using SPSS version 19.0 of the Statistical Software Package. 


\section{Results and Discussions}

\subsection{Treatment performance of $H C W-M F C$}

The different B concentrations were applied to HCW-MFC combined with fluctuations in the inflow in order to create as possible as realistic wastewater composition and flow regime (Allende et al. 2014, Türker et al. 2016). Accordingly, overall B treatment efficiency of the HCW-MFC amounted to $63.4 \%$ with average inflow B concentration of 12.3 $\mathrm{mg} \mathrm{L}^{-1}$ during the experiment period (Table 1). Moreover, the results from the experiment demonstrated that B concentration in outflow was lower than B concentration in inflow, and the decrease in B concentration in the unit 2 was significant as well $(p<0.05)$. This result indicates that HCW-MFC is capable of removing B from the wastewater, and thus this type of system could be used as a bio-filter tool to prevent the B pollution over the world. On the other hand, the removal efficiency for B in the present the HCW-MFC system was found to be relatively higher than efficiencies of other types of CW systems. For example, Ye et al. (2003) reported 32\% B removal from electric utility wastewater in a surface flow CW. Kröpfelová et al. (2009), Türker et al. (2013), and Allende et al. (2014) found B removal of $22.5 \%, 18$, and $32 \%$, respectively in horizontal flow sub-surface CWs. For vertical flow CWs, Allende et al. (2012) reported 12.5\% B removal at the end of the 7 weeks. Furthermore, the removal of $\mathrm{B}$ in horizontal subsurface $\mathrm{CW}$ amounted to $64 \% \mathrm{~B}$ removal rate reported by Türker et al. (2016), a performance very similar to what observed in the present experiment. In this respect, it can be concluded that B treatment performance differs according to the wetland types, thus the selection of wetland type is a key component to obtain higher B removal efficiencies with $\mathrm{CW}$ technologies.

In the present experiment, B has been reduced to the level of outflow concentrations after passing through the unit 1 and a significant decrease was determined after the passage through the unit 2 (Fig 2a). This phenomenon is seen very often while removing contaminants 
253 through hybrid systems because more pollutant pass through the wetland unit during the first 254 phase compared to the second phase, so more sorption sites were available to take up B in the 255 rhizosphere or filtration media of the unit 1. Furthermore, applied B loading rates and 256 corresponding mass removal rates of $\mathrm{B}$, together with the coefficient of determination $\left(R^{2}\right)$ 257 values obtained by regression analysis for the HCW-MFC are also represent in Fig. 2b. It can 258 be seen that the boron mass removal rates of the HCW-MFC $\left(0.002-0.29 \mathrm{mg} / \mathrm{m}^{2} / \mathrm{d}\right)$ showed 259 strong correlation with incoming loads, with $R^{2}=$ values of 0.9195 . Various authors also 260 found similar result associated with the relation between loading rates and mass removal rates 261 in their studies (Turker et al. 2013, Allende et al. 2014, Ye et al. 2003). It is important to note 262 that mass removal rate of the HCW-MFC is mostly related to sorption of B in filtration media, 263 accumulation or precipitation in organic based media, and plant uptake (Türker et al. 2016).

264 Correspondingly, B concentration in outflow samples was stably below $2.4 \mathrm{mg} \mathrm{L}^{-1}$ 265 (drinking water safety limit) during the first 35 days, whereas outflow concentrations from 266 unit 1 and unit 2 were found to be higher than $2.4 \mathrm{mg} \mathrm{L}^{-1}$ when inflow exceeded 6.5 and 267 higher B mg L ${ }^{-1}$ (Fig 2). Therefore, it can be hypothesized that the HCW-MFC has a potential 268 for remediating wastewater below drinking water safety limit and further experiment are 269 needed to test this question. HCW-MFC design and performance were not firstly aimed at COD, BOD, phosphorus removal, and therefore, no special measures were taken to enhance the removal of those 272 parameters. However, we monitored nitrate and nitrite as nitrogen substrates in wastewater 273 and physicochemical parameters $(\mathrm{pH}$, oxidation reduction redox potential, EC, and 274 temperature) during the experiment period. Monitored average nitrate and nitrite 275 concentration and physicochemical parameters in the inflow, unit 1 outflow, and unit 2 276 outflows are given in Table 1 . Overall treatment efficiency of nitrate and nitrite during the 277 experiment period were found as $47.9 \%$ and $19.1 \%$, respectively. The average nitrate and 
278 nitrite amounted to 70.5 and $19.3 \mathrm{mg} \mathrm{L}^{-1}$ and were reduced to 36.5 and $15.2 \mathrm{mg} \mathrm{L}^{-1}$ 279 respectively in the discharged final outflow (Table 1; Fig 3). The results from the present 280 experiment concluded a positive role of the unit 1 on nitrate and nitrite removal because 281 wastewater with high concentrations of these nitrogen substrate were loaded into unit 1 and 282 thus nitrate and nitrite were removed from wastewater. On the other hand, one-way ANOVA 283 indicated that the nitrate value of final outflow was significantly lower than the inflow 284 ( $p<0.05)$, whereas differences for nitrite were not significant $(p>0.05)$ (Fig 3). Nevertheless, 285 it can be concluded that nitrite and nitrate together with B were efficiently reduced by the HCW-MFC.

It can be seen in Table 1 that average oxidation-reduction potentials were measured as 201, 150.6, and $158.2 \mathrm{mV}$ for inflow, unit 1, and unit 2 outflows, respectively. This result indicated that a redox potential greater than $100 \mathrm{mV}$ for unit 1 and unit 2 outflows and an aerobic environment development which facilitated the degradation of nitrate and nitrite by microorganisms to produce electrons in the entire wetland matrix (Oon et al. 2015). The redox values in the outflow samples were stable throughout the after $42^{\text {th }}$ treatment days and remained close to $+150 \mathrm{mV}$ (Fig 3). These results indicated that oxidized iron in both wetland matrixes was relatively stable during the experiment period and the oxidation of ferrous ions may be maintained by the iron-depositing bacteria which are associated with the development of a redox gradient in the wetland matrix (Oon et al. 2015). Moreover, the precipitation of 297 iron-hydroxides in the rhizosphere related to the activities of iron-depositing bacteria 298 probably led to an iron plaque formation and this plaque promotes B binding affinity in the 299 organic-based media, potentially being permanently immobilized in the wetland units as reported by Vymazal and Kröpfelova (2009) for other trace elements. On the other hand, it can be seen in Fig 3 that redox value of the unit 2 are mostly higher than the redox values in the unit 1 during the experiment period. The high redox potential in unit 2 was due to the fact 
that oxygen was introduced from the air as the unit 1 outflow was dosed to unit 2 . Hence, it

304 can be hypothesized that increasing oxygen release into the wetland matrix may have resulted in more Fe precipitation as an iron plaque compared to unit 1, and this may have led to coprecipitation and high action of the iron-depositing bacteria in the unit 1 (Vymazal and Kröpfelová 2009). Theoretically, B removal dynamics could be related to the aerobic oxidation pathways in the wetland matrix, and increased oxygen in the HCW-MFC can have more positive benefits improving $\mathrm{B}$ removal during the experiment period (Türker et al. 2016). However, further researches are needed to understand the relationship between aerobic oxidation pathways or redox conditions of wetland matrix with $\mathrm{B}$ removal efficiency in wetland habitats.

As seen in Table 1, average $\mathrm{pH}$ values in unit 1 outflow and unit 2 outflow were determined to be higher than inflow, supporting that $\mathrm{B}$ as a boric acid form in wastewater were removed by HCW-MFC during the experiment period. Moreover, outflow $\mathrm{pH}$ values were very steady after the first 14 days of monitoring period, and then $\mathrm{pH}$ values for unit 1 and unit 2 had a gradually decreasing trend until $56^{\text {th }}$ days. Afterwards, $\mathrm{pH}$ values showed a 318 slight fluctuation near neutral $\mathrm{pH}$ until at the end of the experiment (Fig 3). As previously

319 reported by various authors, availability of B for plants and media in the wetland habitats increases near neutral $\mathrm{pH}$ levels, and thus $\mathrm{pH}$ values obtained from the present experiment create a matrix which is available for B retention in filtration media and T.latifolia during the study period (Türker et al. 2016, Allende et al. 2012).

Average EC values of outflow from both the unit 1 and unit 2 were higher than those 324 of the inflow during the experiment period (Table 2). Moreover, EC values in final outflow 325 and unit 1 outflow showed high fluctuation ranged from 734 to $1994 \mu \mathrm{S} \mathrm{cm}^{-1}$ and 796 to 1830 $326 \mu \mathrm{S} \mathrm{cm}{ }^{-1}$, respectively (Fig 3). This result indicated that the unit 2 outflow contained more 327 anion and caution ions; however those ions were reduced more in the unit 1 during the 
experiment period. The data obtained from redox potential also support this phenomenon, and

329 it can be seen that unit 2 outflow contained higher redox potential, suggesting that more electrons were found in the aforementioned environment compared to the unit 1 outflow. fluctuation from 20 to $26{ }^{\circ} \mathrm{C}$ during the experiment period. Moreover, the temperature of the unit 1 outflow was slightly higher at the very beginning of the experiment while being very steady at the end of the study (Fig 3).

\subsection{Bioelectric production with HCW-MFC}

A series of comparative daily measurements of voltage in the unit 1 and the unit 2 were done to analyze the electricity generation from the HCH-MFC. Voltage readings across

339 the $1000 \Omega$ external resistor were taken during treatment and the results are shown in Fig 4a.

340 As seen in the mentioned figure, the voltages of the two units were very stable during the first

34121 days. Moreover, the voltages of unit 1 varied in the ranges between 0.4 and $1.4 \mathrm{~V}$ during

342 the experiment period. However, the voltages obtained from unit 2 gradually increased after $34321^{\text {th }}$ treatment day, and they ranged between 0.9 and $1.6 \mathrm{~V}$. Clearly, we obtained higher 344 bioelectric production through the unit 2 compared to the unit 1 during the experiment period.

345 The reasonable explanation of such behavior is to more B passing through unit 1 compared to 346 unit 2 during the first phase and high level of B in the inflow was an inhibitor for the activity 347 of microorganisms which are responsible for bioelectric production. Therefore, it can be 348 suggested that the bioelectric production of the HCW-MFC was mostly promoted with B 349 concentrations which were dosed into the wetland units during the experiment period. It is 350 interesting to note that we found more nitrogen substrate such as nitrite and nitrate were 351 reduced by unit 1 compared to the unit 2 during the experiment period. Therefore, our results 352 also demonstrated that high $\mathrm{B}$ concentration in wastewater may have negative effects on the 
decomposition reaction of nitrogen substrates such as nitrate and nitrite which are consumed

354 by the electrogenic microorganisms to sustain their own growth and metabolism. Because excessive B is biologically toxic and it can lead to microbial inhibition which can promote microbial flora including electrogenic bacteria in the wetland units. Consequently, the efficiency of electric production would diminish due to the lower microbial population and the decrease in microbial activity at the higher B concentrations. However, further researches are needed to investigate the effect of $\mathrm{B}$, other trace elements, as well as heavy metals on electrogenic bacteria in CWs coupled with microbial fuel cell.

The highest maximum power density for the wetland units were $40 \mathrm{mWatt} / \mathrm{m}^{2}$ (with current density of $45 \mathrm{~mA} / \mathrm{m}^{2}$ ) and $78 \mathrm{mWatt} / \mathrm{m}^{2}$ (with $105 \mathrm{~mA} / \mathrm{m}^{2}$ current density) in the unit 1 (Fig 4b) and unit 2 (Fig 4c), respectively. On the other hand, the power density and the current density were decreased with increasing B concentration in wastewater. The average 365 power density and current density were found to be $39.2 \mathrm{mWatt} / \mathrm{m}^{2}$ and $7.98 \mathrm{~mA} / \mathrm{m}^{2}$ respectively for unit 1 average inflow with $12.3 \mathrm{mg} \mathrm{L}^{-1} \mathrm{~B}$ concentration while the values were 367 further increased to $75.7 \mathrm{mWat} / \mathrm{m}^{2}$ and $19.8 \mathrm{~mA} / \mathrm{m}^{2}$ respectively in case of $5.5 \mathrm{mg} \mathrm{L}^{-1}$ of 368 average B in wastewater. The decrease in power density and current density with an increase 369 in concentration of B in average inflow is probably due to the effect of increased level of B toxicity on microorganism associated with bioelectric production. Therefore, it can be

371 hypothesized that high $\mathrm{B}$ concentration negatively affects the microorganisms' activities

372 which are catalyzed to the electron flow from anode to the cathode as a result of biodegraded

373 nitrogen based substrate in wetland matrix. Similar results were also found by various 374 researchers who showed toxic effects of contaminants when concentration were high 375 (Corbella et al. 2015, Fang et al. 2015, Yadav et al. 2012). 
The selection of plant species is an important issue in the CWs and related to their 380 lifespan (Vymazal and Kröpfelová 2009). In the monitored period, the survival rates of T.latifolia in units after the cultivation period were found to be higher than $75 \%$ according to Türker et al. (2013). The healthy growth trend of plants demonstrated that T.latifolia was acclimatizing and reproducing well in both unit 1 and unit 2 which were fed with wastewater containing Hoagland medium before B application. Plant height in both unit 1 and unit 2 were monitored during the operation of units and the results are shown in Table 2. The average plant height in the experiment was measured as $79.8 \mathrm{~cm}$ and $99.6 \mathrm{~cm}$ for unit 1 and unit 2, respectively. Moreover, T.latifolia height in unit 1 and unit 2 ranged from 48 to $100 \mathrm{~cm}$ and 388 from 88 to $109 \mathrm{~cm}$ respectively during the experiment period. These results suggested that 389 T.latifolia in the wetland units showed a good resistance to alterations in B dosage, and thus higher growth rate and proliferous germination level were achieved for T.latifolia in wetland 391 units during the experimental period. Therefore, we recommend that T.latifolia is a well 392 suited option against potential toxic effects of B.

The photosynthetic pigments in T.latifolia were determined to assess B toxicity during 394 the experiment period. The levels of the chlorophyll $a$ and $b$ pigment concentrations for 395 T.latifolia in the wetland units are shown in Table 2. The chlorophyll pigment concentrations 396 of T.latifolia in unit 2 were higher than those in unit 1. It may be explained by several causes 397 such as operational conditions and origin associated with excess B concentrations in the 398 wastewater. Nevertheless, higher chlorophyll content in unit 2 may indicate an apparently 399 higher resistance of T.latifolia to the application of B wastewater. The results of the biomass production both in unit 1 and unit 2 are shown in Table 2. 401 According to present the results at the end of the study, the whole plant biomass production 402 was found as 268 and $305\left(\mathrm{DW} \mathrm{g} \mathrm{m}^{-2}\right.$ ) for T.latifolia in unit 1 and unit 2, respectively. 
Clearly, T.latifolia in unit 2 produced higher biomass compared to the plants in unit 1 during 404 the experiment period. Its reasonable explanations might be that T.latifolia growing in unit 1 was exposed more B during the study as the inflow was firstly dosed into unit 1 according to operational conditions, and that's why we obtained lower biomass production in unit 1 . Therefore, it is recommended that managers and environmental strategists should take into 408 consideration the potential B toxicity effect on plant growth and biomass production for the 409 HCW-MFC in their experiment plan. On the other hand, higher biomass production in unit 2 might also have catalyzed more bioelectric production compare to bioelectric production from 411 unit 1 during the experiment period (Fang et al., 2013). Expectedly, more biomass production 412 in unit 2 could have enhanced the cell voltage, and reduced the internal resistance of unit 2, so 413 thus we obtained more bioelectric compared to unit 1 (Fig 4a).

414 Boron content for T.latifolia growing in unit 1 and unit 2 are also given Table 2. It can 415 be seen in Table 2 that B content of T.latifolia growing in unit 1 was approximately $200 \mathrm{mg}$ $416 \mathrm{~kg}^{-1}$ higher than the plants in the unit 2. It was an expected result because higher concentration 417 of B predominantly flowed in unit 1, and so individuals of T.latifolia were exposed to more B 418 compared to the plants growing in unit 2. Moreover, it can be also hypothesized that higher 419 concentrations of $\mathrm{B}$ as a form of boric acid are transmitted to unit 1 and thus more B was 420 available for T.latifolia uptake in this unit. It is because B is taken up by plant organisms from 421 water mainly as a form of boric acid and stored in leaf, stem, root, and flower (Kröpfelová et 422 al. 2009). Probably, the presence of high concentrations of B in unit 1 led to a significant 423 effect on B uptake by the plants, suggesting that individuals of T.latifolia could play a more 424 crucial role associated with B removal depending on its initial concentration (Türker et al. 425 2016). Various researchers also reported that some cattail species have direct role in B 426 purification process in different type of CWs (Ye et al. 2003; Türker et al. 2014a; Türker et al. 427 2016). 

higher nitrogen content than the stems and roots/rhizomes of individual plants growing in both unit 1 and unit 2 (Table 2). This result suggested that a nitrogen transport corridor occurred in T.latifolia, and that $\mathrm{N}$ is transported to upper parts of the plant organs such as 432 leaves and stems after being taken up by roots/rhizomes. Therefore, harvesting of 433 aboveground plant organs such as leaves from HCW-MFC might be an effective strategy to 434 remove the nitrogen based pollutants from wastewater (Türker et al., 2013). On the other 435 hand, it can be seen in Table 2 that nitrogen content in T.latifolia growing in unit 1 was found 436 to be higher than T.latifolia growing in unit 2 in the experiment period. This result also 437 showed evidence for more nitrogen substrates such as nitrite and nitrate was reduced by unit 1 438 during the first phase of the experiment.

\subsection{Filtration media analysis of $H C W-M F C$}

Total B concentration, extractable B (plant available B form as boric acid) amount, and other parameters ( $\mathrm{pH}, \mathrm{EC}$, redox, nitrogen content, and sediment texture) at the end of the

443 experiment are given in Table 3. The results showed that more than $700 \mathrm{mg} \mathrm{kg}^{-1}$ and $500 \mathrm{mg}$ $444 \mathrm{~kg}^{-1} \mathrm{~B}$ retained in the filtration media of unit 1 and unit 2, respectively. Therefore, it can be 445 suggested that filtration medias in wetland units have the potential to remove B from 446 wastewater and thus high level of B was retained in the organic based peat (as using filtration 447 media) during the experiment period. Some reports from the literature also supported our 448 findings that a sorption mechanism in organic based materials is the key element for removal 449 of B in wetland matrix (Allende et al. 2014, Ye et al. 2003). Furthermore, it can be seen in 450 Table 3 that extractable $\mathrm{B}$ concentration in the unit 1 was $3.39 \mathrm{mg} \mathrm{kg}^{-1}$ higher than the unit 2, 451 meaning that a higher number of the sorption sites have taken up B which was available for 452 the plant in unit 1 compared to unit 2 during the experiment period. This situation may also 
explain the higher B content in T.latifolia growing in unit 1 compared to individual plants in unit 2. On the other hand, other parameters such as pH, EC, redox, nitrogen content, and sediment texture can also be considered to have important roles on retained B content in the filtration media of the units. It is because these factors together with flow regime are known to control B adsorption in the wetland matrix (Türker et al. 2016, Allende et al. 2012).

\subsection{Relationships between soil enzymes activities and bioelectric production}

Dehydrogenase, urease, and phosphatase enzymes activities in wetland matrix can provide important information about the quantitative aspects of the quality of living dynamics related to microbial activity and microbial compositions in soil environment (Zhang et al. 2010). However, studies on the relationship between soil enzyme activities and bioelectric production in CWs is still lacking, and no direct research has been performed so far.

The activities of dehydrogenase, urease, and phosphatase in wetland units during the treatment days are shown in Fig 5. It can be seen that enzyme activities except phosphatase gradually increased with increasing bioelectric production both in unit 1 and unit 2 during the experiment period. Dehydrogenase activity in unit 1 and unit 2 increased from 12 to $54 \mu \mathrm{g}$ TPF $\mathrm{g}^{-1} \mathrm{~h}^{-1}$ and 8 to $98 \mu \mathrm{g} \mathrm{TPF} \mathrm{g}^{-1} \mathrm{~h}^{-1}$. Additionally, bioelectric production for the unit 1 and unit 2 increased from 0.55 to $1.43 \mathrm{~V}$ and 1.01 to $1.56 \mathrm{~V}$, respectively. Moreover, we determined a similar trend for urease activity, and thus higher enzyme activity for unit 1 and unit 2 which were measured as 1188 and $2675 \mu \mathrm{g} \mathrm{NH}_{4}{ }^{+} \mathrm{g}^{-1} 48 \mathrm{~h}^{-1}$ respectively when bioelectric production was high. On the other hand, the lowest activity of urease both in unit 1 and unit 2 was observed as 114 and $640 \mu \mathrm{g} \mathrm{NH}_{4}{ }^{+} \mathrm{g}^{-1} 48 \mathrm{~h}^{-1}$ respectively when bioelectric production was low. However, we did not note any discernible temporal trends between phosphatase enzyme activity and bioelectric production in unit 1 and unit 2, and the activity varied from 3.5 to $22.1 \mu \mathrm{g}$ p-nitrophenol $\mathrm{g}^{-1} \mathrm{~h}^{-1}$ and 12.3 to $21.1 \mu \mathrm{g}$ p-nitrophenol $\mathrm{g}^{-1} \mathrm{~h}^{-1}$, 
respectively. Additionally, bioelectric production for unit 1 and unit 2 increased from 0.55 to $1.43 \mathrm{~V}$ and 1.01 to $1.56 \mathrm{~V}$, respectively. These results indicated that bioelectric production in wetland matrix increased with increasing soil enzyme activities, especially of dehydrogenase and urease which are related to cycling of carbon and nitrogen. This may be because the presence of more microbial density catalyzes mineralization and transformation of organic matters and the hydrolysis of urea to carbon dioxide (Zhang et al. 2010). Notably, it can be seen from the present study that bioelectric capacity can be enhanced with increased soil enzyme activities. However, this phenomenon can also be related to B concentrations which were flowing through wetland units during the experiment period. In this respect, we found that soil enzyme activities in unit 2 were higher than the activities in unit 1, suggesting that high concentrations of B can decrease soil enzyme activities in wetland matrix. Therefore, it can also be hypothesized that when the high initial B concentration was dosed into unit 1, the production of the soil enzymes with microorganisms in the unit1 were inhibited more by B compared to unit 2 , and so bioelectric production rises remarkably with wastewater passing from unit 1 to unit 2.

Furthermore, we determined that dehydrogenase and urease activities in unit 1 showed significant correlations as $r=+0.674(p<0.01)$ and $r=+0.767(p<0.01)$ respectively with bioelectric production, whereas there were no significant correlations among phosphatase $(r=$ $0.258 ; p>0.05$ ) enzyme activity and bioelectric production for unit 1 . A significant correlation was found between dehydrogenase activity and bioelectric production for unit 2 ( $r=0.686$; $p<0.01$ ), while we did not find any significant correlations urease and phosphatase enzyme activities with bioelectric production for unit 2 in the experiment period. These results suggested that the monitoring and determining of soil dehydrogenase and urease in wetland matrix could serve as important biomarkers for bioelectric production during the contaminant purification process. Nevertheless, further studies are needed for a deeper understanding on 
503 the relationship between soil enzyme activities and bioelectric production in the wetland 504 systems treating both nitrogen and B from wastewater.

\section{Conclusions}

A HCW-MFC was designed, evaluated, and tested in term of feasibility for B removal 508 and bioelectric production concurrently. 63.4\% B removal average was achieved for

509 wastewater containing average $12.3 \mathrm{mg} \mathrm{L}^{-1}$ inflow B concentrations. This wetland system was 510 also able to remove $47.5 \%$ and $19.1 \%$ nitrate and nitrite from wastewater, respectively. The 511 maximum power density and current density was recorded as $78 \mathrm{mWatt} / \mathrm{m}^{2}$ and $105 \mathrm{~mA} / \mathrm{m}^{2}$ 512 for the last unit in the hybrid system, respectively. Dehydrogenase and urease enzyme 513 activities were strongly correlated with bioelectric production, suggesting that these enzymes 514 might play important roles in bioelectric production in HCW-MFC.

\section{Acknowledgements}

This research did not receive any specific grant from funding agencies in the public,

518 commercial, or not-for-profit sectors.

\section{References}

521 Allende, K.L., Fletcher, T. and Sun, G. (2012) The effect of substrate media on the removal of 522 arsenic, boron and iron from an acidic wastewater in planted column reactors. Chemical 523 Engineering Journal 179, 119-130.

524 Allende, K.L., McCarthy, D. and Fletcher, T. (2014) The influence of media type on removal 525 of arsenic, iron and boron from acidic wastewater in horizontal flow wetland microcosms 526 planted with Phragmites australis. Chemical Engineering Journal 246, 217-228. 
APHA, A. (1998) WEF (American Public Health Association, American Water Works

528 Association, and Water Environment Federation). 1998. Standard methods for the examination of water and wastewater 19.

530 Corbella, C., Guivernau, M., Viñas, M. and Puigagut, J. (2015) Operational, design and 531 microbial aspects related to power production with microbial fuel cells implemented in 532 constructed wetlands. Water Research 84, 232-242.

533 Davis, S.M., Drake, K.D. and Maier, K.J. (2002) Toxicity of boron to the duckweed, 534 Spirodella polyrrhiza. Chemosphere 48(6), 615-620.

535 Doherty, L., Zhao, Y., Zhao, X., Hu, Y., Hao, X., Xu, L. and Liu, R. (2015a) A review of a 536 recently emerged technology: Constructed wetland-Microbial fuel cells. Water Research 85, $537 \quad 38-45$.

538 Doherty, L., Zhao, Y., Zhao, X. and Wang, W. (2015b) Nutrient and organics removal from 539 swine slurry with simultaneous electricity generation in an alum sludge-based constructed 540 wetland incorporating microbial fuel cell technology. Chemical Engineering Journal 266, 7454181

542 Fang, Z., Song, H.-l., Cang, N. and Li, X.-n. (2015) Electricity production from Azo dye 543 wastewater using a microbial fuel cell coupled constructed wetland operating under different 544 operating conditions. Biosensors and Bioelectronics 68, 135-141.

545 Hasenmueller, E.A. and Criss, R.E. (2013) Multiple sources of boron in urban surface waters 546 and groundwaters. Science of the total environment 447, 235-247.

547 Kong, L., Wang, Y.-B., Zhao, L.-N. and Chen, Z.-H. (2009) Enzyme and root activities in 548 surface-flow constructed wetlands. Chemosphere 76(5), 601-608.

549 Kröpfelová, L., Vymazal, J., Švehla, J. and Štíchová, J. (2009) Removal of trace elements in 550 three horizontal sub-surface flow constructed wetlands in the Czech Republic. Environmental 551 Pollution 157(4), 1186-1194. 
Logan, B., Cheng, S., Watson, V. and Estadt, G. (2007) Graphite fiber brush anodes for

553

554

555

556

557

558

559

560

561

562

563

564

565

566

567

568

569

570

571

572

573

574

575

576

increased power production in air-cathode microbial fuel cells. Environmental science \& technology 41(9), 3341-3346.

Oon, Y.-L., Ong, S.-A., Ho, L.-N., Wong, Y.-S., Oon, Y.-S., Lehl, H.K. and Thung, W.-E. (2015) Hybrid system up-flow constructed wetland integrated with microbial fuel cell for simultaneous wastewater treatment and electricity generation. Bioresource technology 186, 270-275.

Schoderboeck, L., Mühlegger, S., Losert, A., Gausterer, C. and Hornek, R. (2011) Effects assessment: Boron compounds in the aquatic environment. Chemosphere 82(3), 483-487.

Turker, O.C., Bocuk, H. and Yakar, A. (2013) The phytoremediation ability of a polyculture constructed wetland to treat boron from mine effluent. J Hazard Mater 252-253, 132-141.

Türker, O.C., Vymazal, J. and Türe, C. (2014) Constructed wetlands for boron removal: A review. Ecological Engineering 64, 350-359.

Türker, O.C., Türe, C., Böcük, H., Çiçek, A. and Yakar, A. (2016) Role of plants and vegetation structure on boron (B) removal process in constructed wetlands. Ecological Engineering 88, 143-152.

Vymazal, J. and Kröpfelová, L. (2009) Removal of organics in constructed wetlands with horizontal sub-surface flow: a review of the field experience. Science of the total environment 407(13), 3911-3922.

Vymazal, J. (2013) The use of hybrid constructed wetlands for wastewater treatment with special attention to nitrogen removal: a review of a recent development. Water research 47(14), 4795-4811.

Wellburn, A.R. (1994) The spectral determination of chlorophylls a and b, as well as total carotenoids, using various solvents with spectrophotometers of different resolution. Journal of plant physiology 144(3), 307-313. 
577 Wolska, J. and Bryjak, M. (2013) Methods for boron removal from aqueous solutions-A 578 review. Desalination 310, 18-24.

579 Yadav, A.K., Dash, P., Mohanty, A., Abbassi, R. and Mishra, B.K. (2012) Performance 580 assessment of innovative constructed wetland-microbial fuel cell for electricity production 581 and dye removal. Ecological Engineering 47, 126-131.

582 Ye, Z., Lin, Z.-Q., Whiting, S., De Souza, M. and Terry, N. (2003) Possible use of 583 constructed wetland to remove selenocyanate, arsenic, and boron from electric utility 584 wastewater. Chemosphere 52(9), 1571-1579.

585 Zhang, C.-B., Wang, J., Liu, W.-L., Zhu, S.-X., Liu, D., Chang, S.X., Chang, J. and Ge, Y. 586 (2010) Effects of plant diversity on nutrient retention and enzyme activities in a full-scale 587 constructed wetland. Bioresource technology 101(6), 1686-1692.

588 Zhao, Y., Collum, S., Phelan, M., Goodbody, T., Doherty, L. and Hu, Y. (2013) Preliminary 589 investigation of constructed wetland incorporating microbial fuel cell: batch and continuous 590 flow trials. Chemical Engineering Journal 229, 364-370.

591

592

593

594

595

596

597

598

599

600

601 
603

604 Fig. 1. The schematic demonstration of the hybrid constructed wetland couple with microbial 605 fuel cell (HCW-MFC).

606 Fig. 2. Inflow and outflow properties both in unit 1 and unit 2 (a) and mass removal rate of 607 HCW-MFC in the experiment period (b). Error bars indicate standard deviation.

608 Fig. 3. Nitrate and nitrite concentrations, as well as physicochemical parameter of inflow and 609 outflow samples both in the unit 1 and unit 2 during the experiment period. Error bars indicate 610 standard deviation.

611 Fig. 4. Voltage output of unit 1 and unit 2 (a), power density and current density monitoring 612 of unit 1 (b) and unit 2 (c) in the experiment period.

613 Fig. 5. The activities of dehydrogenase, urease, and phosphatase enzymes both in unit 1 and 614 unit 2 based on bioelectric production in the experiment period. Error bars indicate standard 615 deviation. 


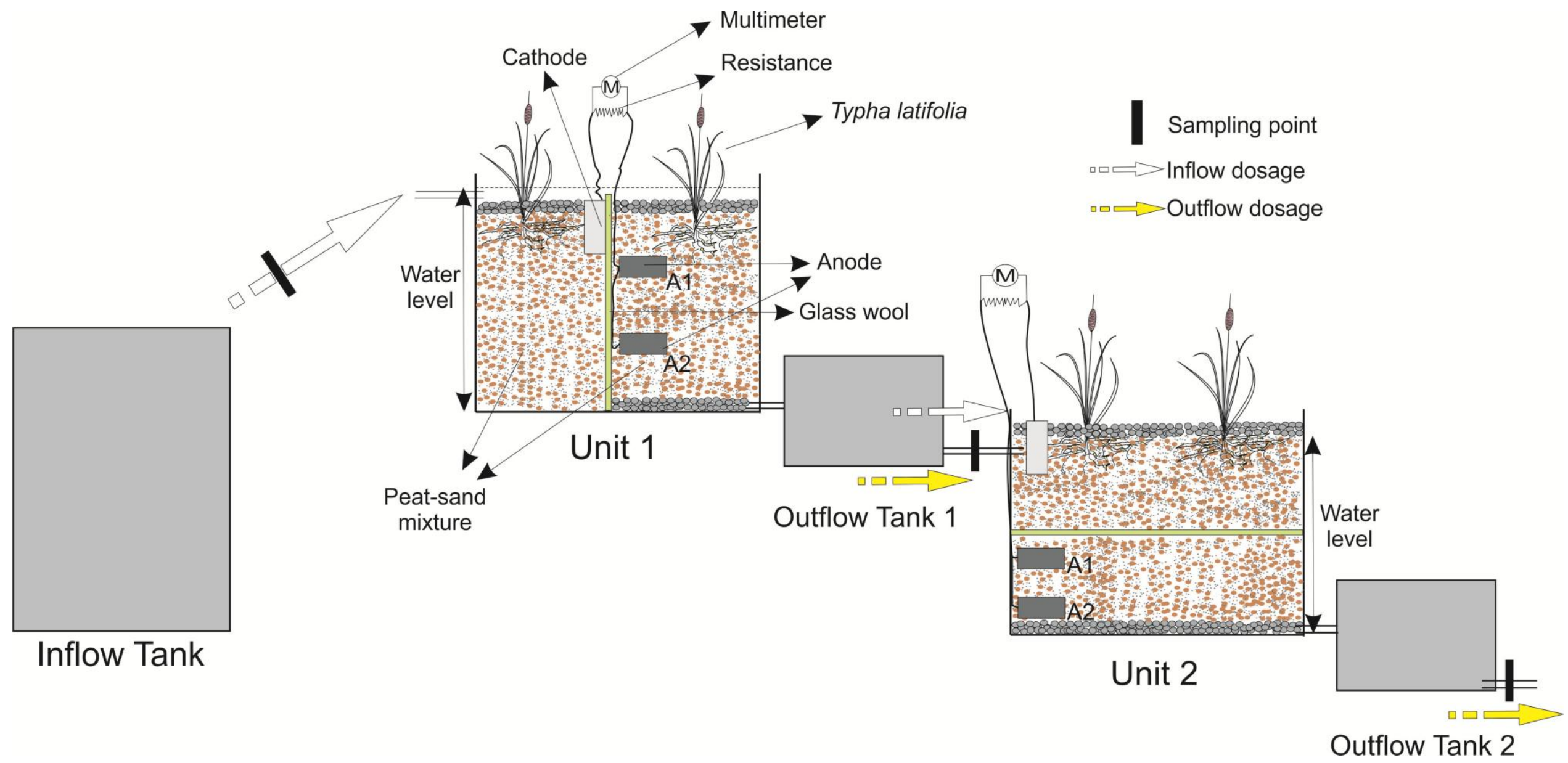

Fig. 1. The schematic demonstration of the hybrid constructed wetland couple with microbial fuel cell (HCW-MFC). 


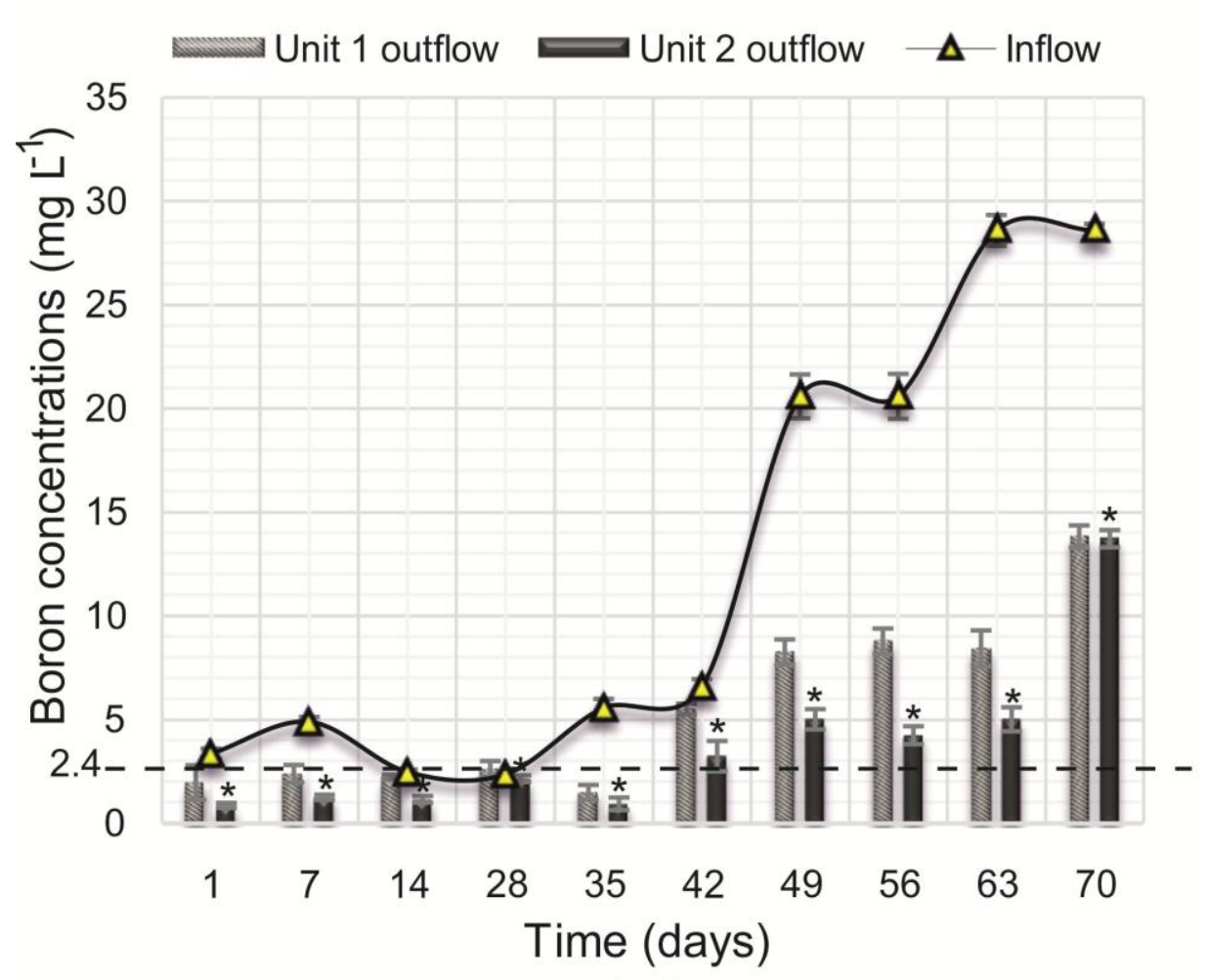

(a)

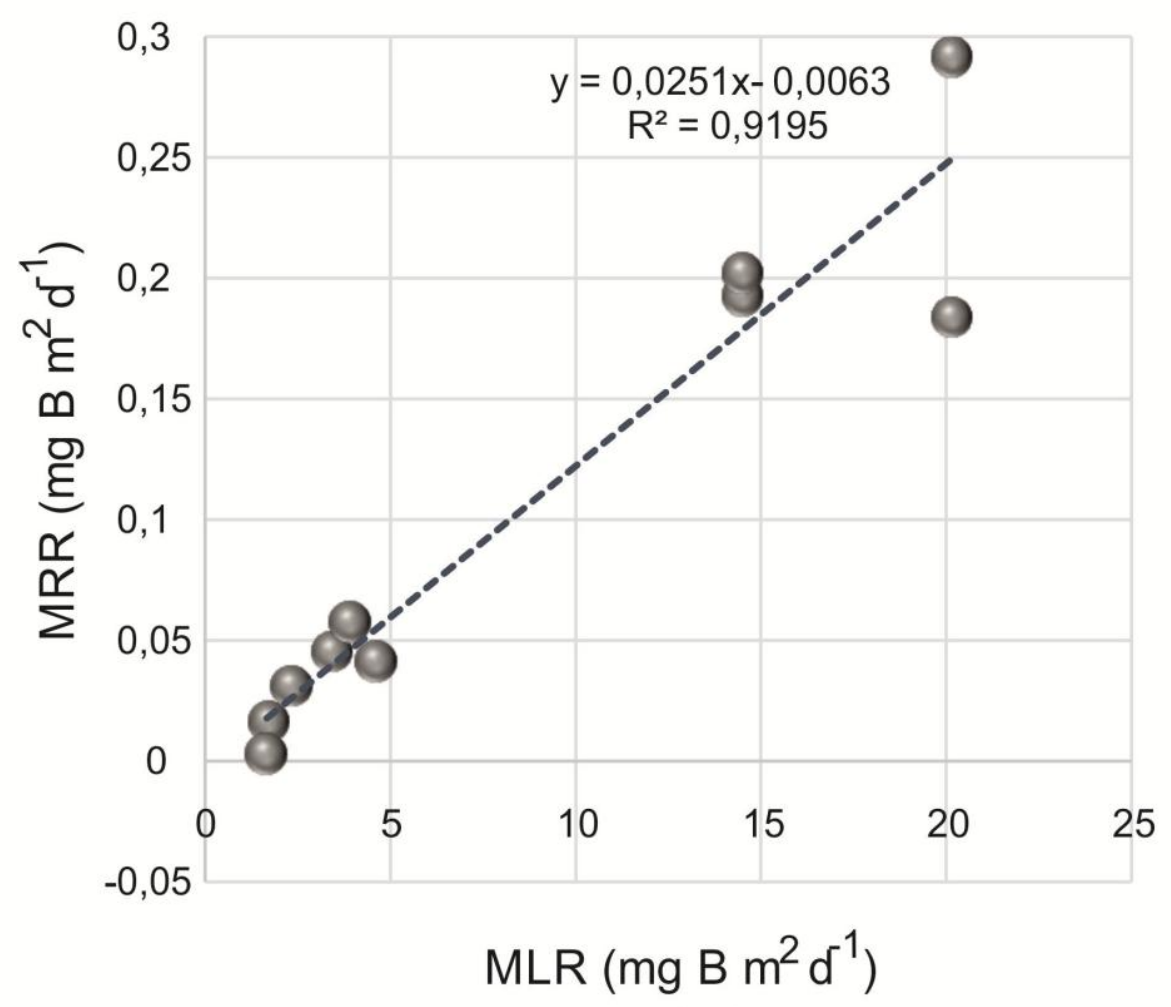

(b)

Fig. 2. Inflow and outflow properties both in unit 1 and unit 2 (a) and mass removal rate of HCW-MFC in the experiment period (b). An asterisk (*) denotes significant difference $(p<0.05)$ of the mean value between the inflow and outflow in the treatment period. Error bars indicate standard deviation. 

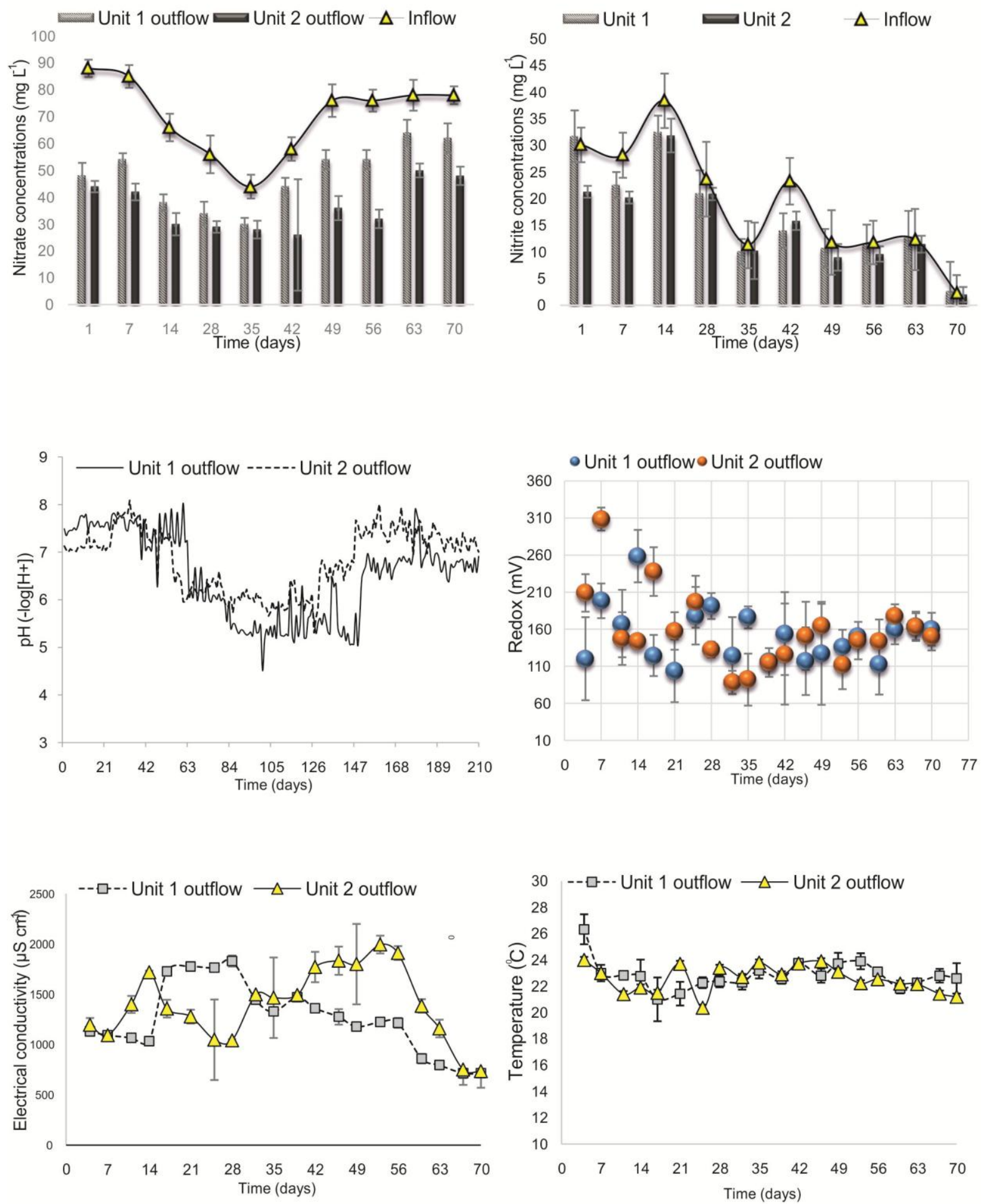

Fig. 3. Nitrate and nitrite concentrations, as well as physicochemical parameter of inflow and outflow samples both in the unit 1 and unit 2 during the experiment period. Error bars indicate standard deviation. 

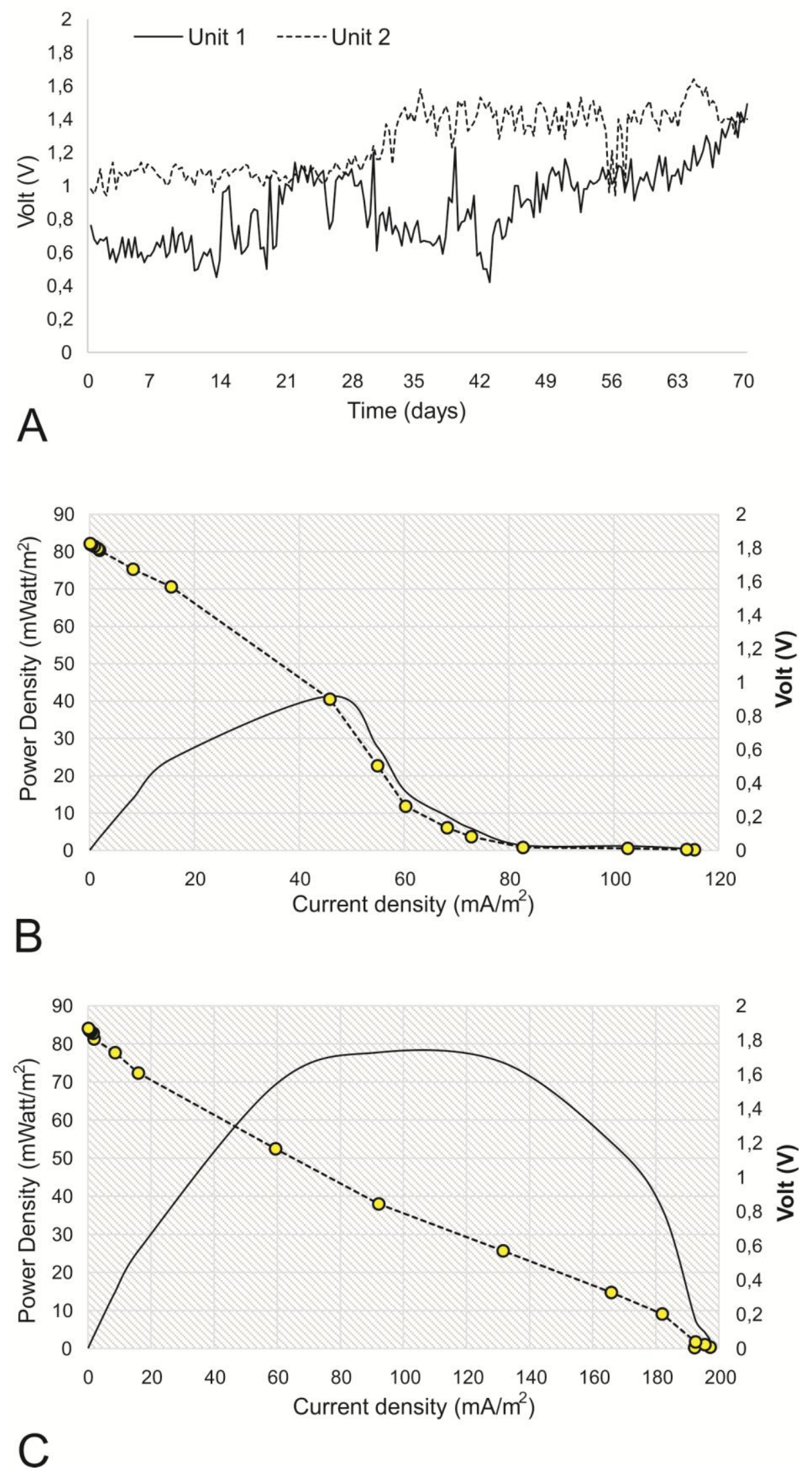

Fig. 4. Voltage output of unit 1 and unit 2 (a), power density and current density monitoring of unit 1 (b) and unit 2 (c) in the experiment period. 
(a)
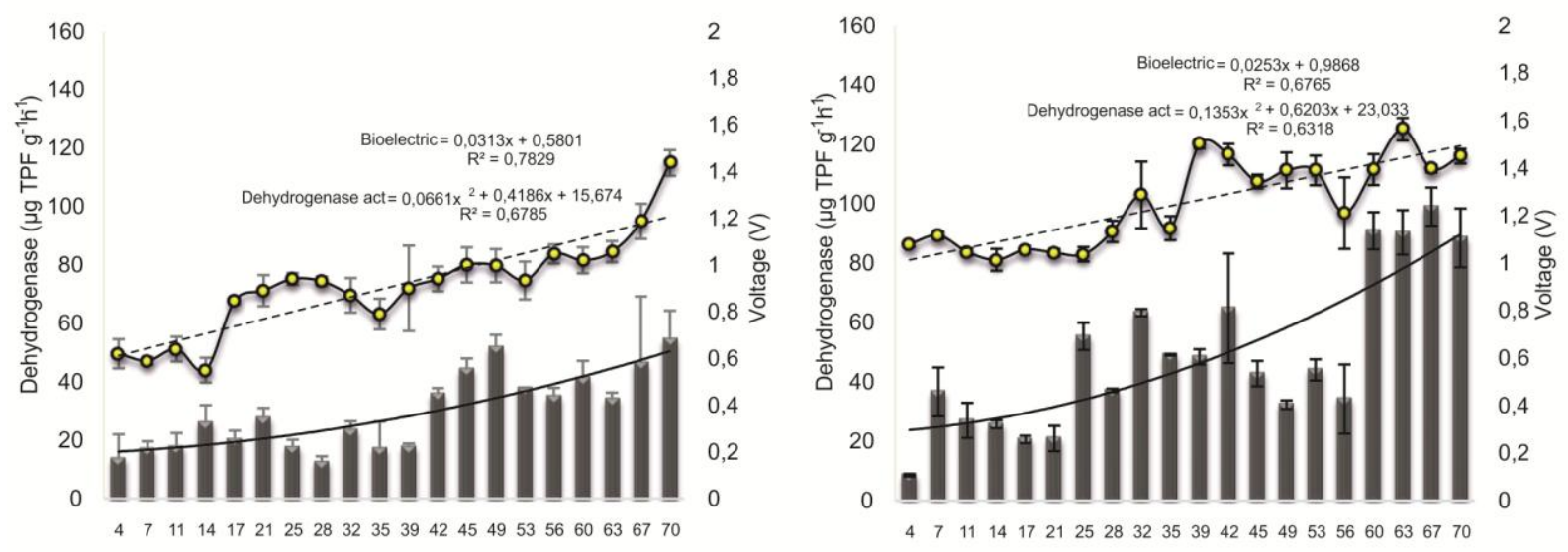

(b)
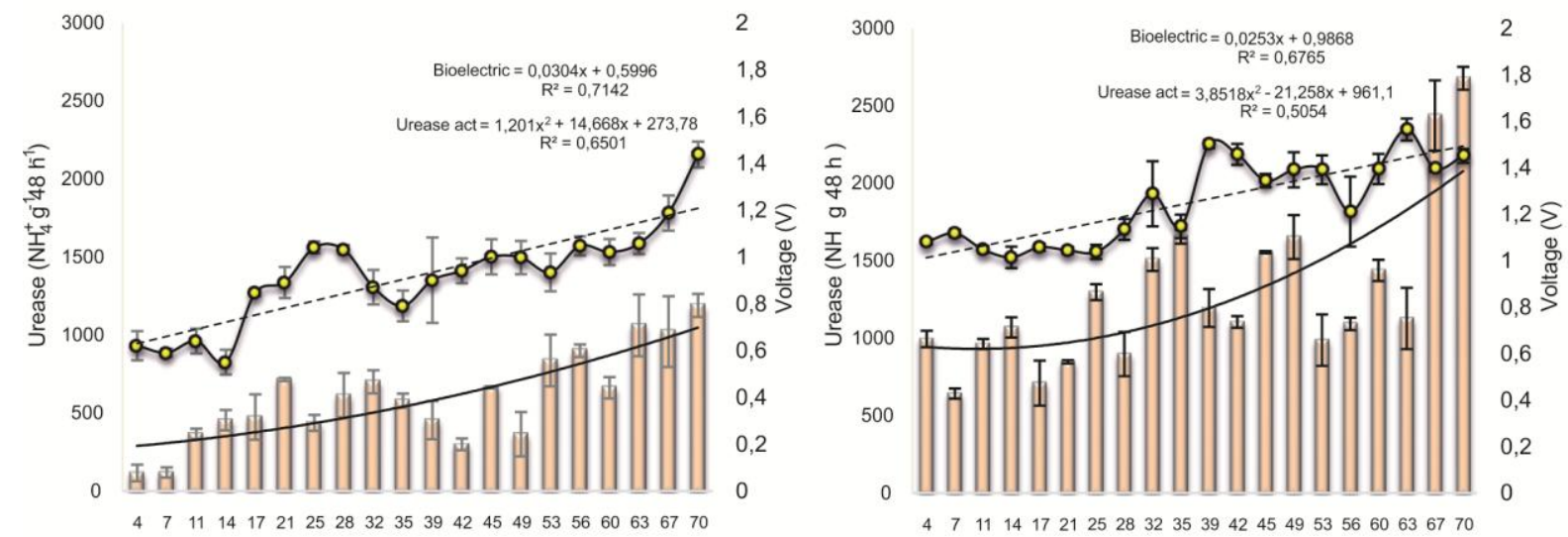

(c)

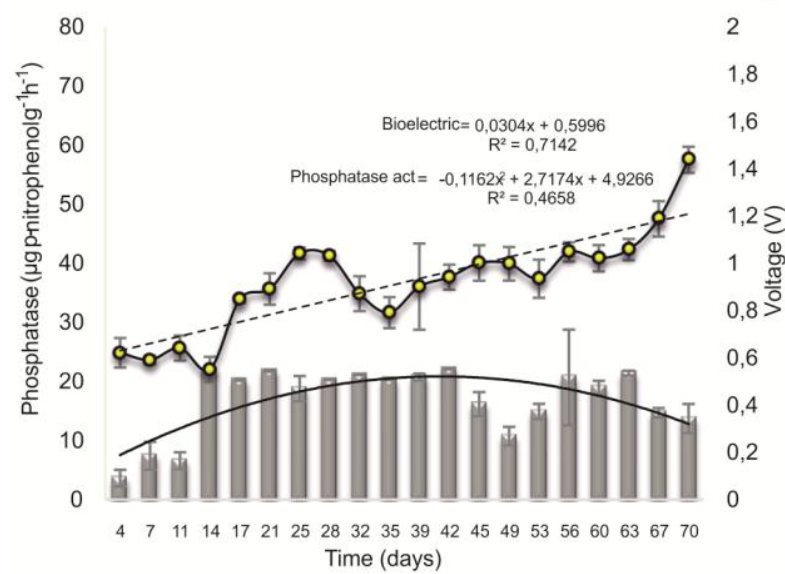

Unit 1

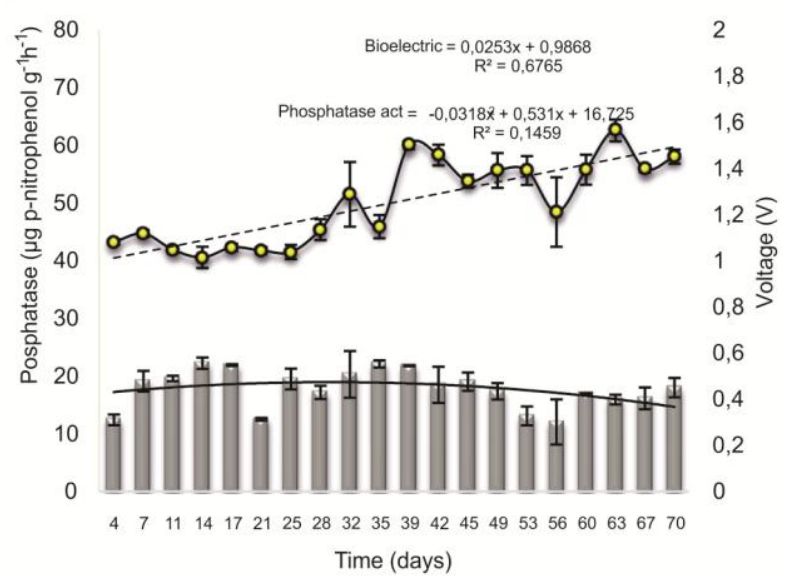

Unit 2

Fig. 5. The activities of dehydrogenase (a), urease (b), and phosphatase (c) enzymes both in unit 1 and unit 2 based on bioelectric production in the experiment period. Error bars indicate standard deviation. 
Table 1. Overall treatment performance of hybrid constructed wetland with microbial fuel cell during the experiment period. Range in parentheses.

\begin{tabular}{ccccc}
\hline & Inflow & Unit 1 outflow & Unit 2 outflow & Overall treatment efficiency(\%) \\
\hline Boron $\left(\mathrm{mg} \mathrm{L}^{-1}\right)$ & $12.3(2-28)$ & $5.5(1.4-13)$ & $3.7(0.8-13)$ & 63.4 \\
\hline Nitrate $\left(\mathrm{mg} \mathrm{L}^{-1}\right)$ & $70.5(44-88)$ & $48.2(30-64)$ & $36.5(26-50)$ & 47.9 \\
\hline Nitrite $\left(\mathrm{mg} \mathrm{L}^{-1}\right)$ & $19.3(2.3-38.4)$ & $16.9(2.6-32)$ & $15.2(2.03-31)$ & - \\
\hline $\mathrm{pH}(-\log [\mathrm{H}+])$ & $6.14(5.98-6.33)$ & $6.5(4.66-8.01)$ & $6.8(5.18-8.05)$ & - \\
\hline Redox $(\mathrm{mV})$ & $201(157-271)$ & $150.6(103-198)$ & $158.2(88.5-308)$ & - \\
\hline EC $\left(\mu \mathrm{S} \mathrm{cm}{ }^{-1}\right)$ & $993(428-1937)$ & $1249(796-1830)$ & $1395(734-1994)$ & - \\
\hline Temperature $\left({ }^{\circ} \mathrm{C}\right)$ & $22.5(20.4-23)$ & $22.8(21-26.3)$ & $22.5(21.2-24)$ & \\
\hline
\end{tabular}


Table 2. Plant monitoring, biomass production, boron (B) concentrations, and nitrogen (N) content in the experiment period. Range in parentheses.

\begin{tabular}{|c|c|c|c|c|c|c|c|c|}
\hline & \multicolumn{4}{|c|}{ Typha latifolia (Cattail) growing in Unit 1} & \multicolumn{4}{|c|}{ Typha latifolia (Cattail) growing in Unit 2} \\
\hline & Leaves & Stems & Roots/Rhizomes & Whole plant & Leaves & Stems & Roots/Rhizomes & Whole plant \\
\hline Plant Height $(\mathrm{cm})$ & $79.8(48-100)$ & - & - & & $99.6(88-109)$ & - & - & \\
\hline Chlorophyll-a content $\left(\mu \mathrm{g} \mathrm{L}^{-1}\right)$ & $24.1(19.7-33.4)$ & - & - & - & $28.06(26.4-35.7)$ & - & - & - \\
\hline Chlorophyll-b content $\left(\mu \mathrm{g} \mathrm{L}^{-1}\right)$ & $13.4(10.09-23.02)$ & - & - & - & $16.1(12.7-20.7)$ & - & - & - \\
\hline Biomass Production $\left(\mathrm{DW} \mathrm{g} / \mathrm{m}^{2}\right)$ & 175 & 15.5 & 77.4 & 268 & 132.5 & 29.1 & 100.1 & 305 \\
\hline Boron concentrations (mg/kg) & - & - & - & $>700$ & - & - & - & $>500$ \\
\hline Nitrogen $(\mathrm{N})$ content $(\%)$ & $2.57(2.51-2.68)$ & $2.25(2.19-2.33)$ & $1.67(1.51-1.74)$ & - & $2.15(2.05-2.22)$ & $1.19(1.01-1.38)$ & $1.53(1.48-6)$ & - \\
\hline
\end{tabular}


Table 3. Chemical and Physical analyzes of filtration media from unit 1 and unit 2 at the end of the experiment. Range in parentheses.

\begin{tabular}{ccc}
\hline & Unit 1 & Unit 2 \\
\hline Total amount of B $\left(\mathbf{m g ~ k g}^{-1}\right)$ & $>350$ & $>300$ \\
\hline Extractable B $\left(\mathbf{m g ~ k g}^{-1}\right)$ & $10.83(7.84-15.45)$ & $7.44(4.11-12.7)$ \\
\hline pH $(-\log [\mathbf{H}+])$ & $8(7.96-8.06)$ & $7.99(7.91-8.04)$ \\
\hline Redox $(\mathbf{m V})$ & $81.2(80.5-81.8)$ & $82.7(81.6-84.5)$ \\
\hline EC & $434(408-443)$ & $542(515-542)$ \\
\hline N $(\%)$ & $0.527(0.34-0.795)$ & $0.2621(0.237-0.272)$ \\
\hline Sediment Texture & sand & \\
\hline
\end{tabular}

